\title{
Leukocyte-endothelium interactions in cutaneous inflammatory processes
}

\author{
Jonathan N. W. N. Barker' ${ }^{1}$ and Brian J. Nickoloff ${ }^{2}$ \\ Laboratory of Applied Dermatopathology, St. John's Institute of Dermatology, United Medical \\ and Dental Schools, Guy's Hospital, London SE1 9RT, UK \\ ${ }^{2}$ Department of Pathology, University of Michigan Medical Center, Ann Arbor, MI 48109, USA
}

\section{Introduction}

Migration of leukocytes into soft tissues is a pivotal event in inflammatory responses involving all organs. These processes are crucial in host responses to injury or infection as highlighted by the inherited disease "leukocyte adhesion deficiency", in which failure of migration results in recurrent life - threatening soft-tissue infections [72]. Alternatively, leukocyte migration may contribute to the pathology of many disorders, including inflammatory cutaneous diseases.

As first witnessed by Cohnheim in 1889 [15] and later by Clarke in 1935 [14] using intravital microscopy, the first step in leukocyte localisation to sites of inflammation is "margination", an event whereby leukocytes leave the central stream of blood flow in post-capillary venules. Leukocytes then interact with endothelium by "rolling" along the luminal surface, a process which occurs within minutes of the inflammatory stimulus. As the inflammatory process progresses, the number of rolling cells increases and their velocity decreases, until they come to a halt, or "arrest". As a consequence of these events, leukocytes may then migrate through endothelial cell junctions along the vessel wall and into tissues, a process termed "diapedesis". Cohnheim [15] remarked "we have here to deal with a molecular change of the vessel walls". One hundred years later, the molecular basis for leukocyte interaction with endothelium is being established.

These events are clearly highly relevant to leukocyte recruitment into skin. For leukocytes to gain access to the dermis and epidermis, they must first leave the circulation, by adhering to and migrating through dermal blood vessel walls, and subsequently migrate through cutaneous structures along chemotactic gradients to the inflammatory focus. Studies suggest that migration is not random but controlled by precise processes, regulating recruitment of appropriate leukocyte subpopulations. For example, cutaneous lymphocytic inflammation is characterised by $\mathrm{T}$ cell accumulation, whereas in the gut $\mathrm{B}$ cell accumulation predominates. 
This chapter examines the molecular basis of leukocyte-endothelium interactions and their relevance to cutaneous inflammatory processes.

\section{In vitro molecular basis for leukocyte adherence to endothelial cells}

Leukocyte adherence to post capillary venular endothelium is a critical step in localisation of leukocytes at sites of inflammation [10]. These events are mediated via interactions between adhesion receptors on circulating leukocytes and their ligands induced by a variety of pro-inflammatory factors on activated endothelial cells. Characterisation of the molecules responsible for these events has been elucidated using static in vitro models of adhesion whereby purified peripheral blood leukocytes and/or leukocyte cell lines adhere to monolayers of human umbilical vein endothelial cells (HUVEC). To date at least five separate adhesion ligands have been characterised on activated HUVECs, namely intercellular adhesion molecule 1 (ICAM-1; CD54) [66], intercellular adhesion molecule 2 (ICAM-2) [74], endothelial leukocyte adhesion molecule 1 (ELAM-1; LECAM-2) [8], vascular cell adhesion molecule 1 (VCAM-1; INCAM-110) [57] and granule membrane protein (GMP)-140(CD62; LECAM-3; PADGEM) [25] (Table 1).

ICAM-1, ICAM-2 and VCAM-1, all members of the immunoglobulin gene superfamily, are single chain molecules characterised by repeated immunoglobulin-like extracellular domains: ICAM-1 has five, ICAM-2 has two and VCAM-1 has six. Both ICAM-1 and ICAM-2 serve as ligands for lymphocyte functionassociated antigen (LFA)-1 (CD11a/CD18) [73, 74], a $\beta 2$ integrin comprising two

Table 1. Vascular adhesion molecules

\begin{tabular}{|c|c|c|c|}
\hline Name & Synonyms & Ligand & Cell type \\
\hline \multicolumn{4}{|l|}{ Selectins } \\
\hline ELAM-1 & $\begin{array}{l}\text { LECAM-2 } \\
\text { E-Selectin }\end{array}$ & $\begin{array}{l}\text { Sialyl Lewis X } \\
\text { CLA }\end{array}$ & $\begin{array}{l}\text { Neutrophil, } \\
\text { Monocyte } \\
\text { Memory T cell }\end{array}$ \\
\hline GMP-140 & $\begin{array}{l}\text { LECAM-3 } \\
\text { P-Selectin } \\
\text { CD62 } \\
\text { PADGEM }\end{array}$ & Sialyl Lewis $\mathrm{X}$ & Neutrophil \\
\hline \multicolumn{4}{|c|}{ Immunoglobulins } \\
\hline \multirow[t]{2}{*}{ ICAM-1 } & CD54 & $\begin{array}{l}\text { LFA-1 } \\
\text { (CD1 la/CD18) }\end{array}$ & All leukocytes \\
\hline & & $\begin{array}{l}\mathrm{Mac}-1 \\
(\mathrm{CD} 11 \mathrm{~b} / \mathrm{CD} 18)\end{array}$ & $\begin{array}{l}\text { Neutrophil, } \\
\text { Monocyte }\end{array}$ \\
\hline ICAM-2 & & LFA-1 & All leukocytes \\
\hline VCAM-1 & INCAM-110 & $\begin{array}{l}\text { VLA-4 } \\
\text { (CD49d/CD29) }\end{array}$ & $\begin{array}{l}\text { Lymphocyte, } \\
\text { Monocyte, } \\
\text { Eosinophil }\end{array}$ \\
\hline
\end{tabular}


non-covalently linked peptide chains expressed on the surface of all leukocytes. Adherence between LFA-1 and ICAM-1 is dependent on leukocyte activation [18], which increases avidity of LFA-1 for ICAM-1, but not increased surface expression of LFA-1. In addition, ICAM-1 serves as a ligand for a second $\beta 2$ integrin, MAC-1 (CR3, Mo-1; CD11b/CD18) [16] expressed predominantly on the surface of monocytes and neutrophils. VCAM-1 was initially described and functionally characterised by screening an interleukin (IL)-1 HUVEC expression library utilising a functional assay for cell-cell adhesion [57]. It acts as a ligand for the $\beta 1$ integrin very-late activation antigen 4 (VLA-4; CD49d/CD29), at a site separate from the fibrorectin binding domain [20]. VLA-4 is maximally expressed on memory-type $\mathrm{T}$ lymphocytes and also on eosinophils and monocytes.

Both ELAM-1 and GMP-140 belong to a family of molecules called selectins or Lec-Cams [71]. Structural analysis of these molecules reveals an extracellular $\mathrm{N}$-terminal domain homologous to a variety of calcium-dependent lectins, coupled to an epidermal growth factor-like domain of amino acids that is followed by short consensus repeat motifs, as found in complement-activation regulatory proteins. Both ELAM-1 [46] and GMP-140 [43] recognise sialylated derivates of the Lewis $\mathrm{X}$ oligosaccharide (sLx) on the surface of leukocytes, particularly that associated with the selectin LECAM-1 [59]. To date, GMP-140 has been shown to act solely as a ligand for neutrophils while ELAM-1 binds neutrophils, monocytes and memory $\mathrm{T}$ lymphocytes [60, 69]. It has been suggested that ELAM-1 may act as a skin-specific addressin for skin homing memory $\mathrm{T}$ cells as identified by the monoclonal antibody HECA-452 [58], which recognises the epitope responsible for ELAM-1 binding [7].

The dynamics of surface expression of these adhesion ligands on HUVECs is specific for each molecule, with induction of selectins (GMP-140 and ELAM-1) preceding immunoglobulin (ICAM-1 and VCAM-1) expression. GMP-140 is stored in cytoplasmic Weibel-Palade bodies of endothelial cells and within minutes of stimulation of HUVECs in vitro by acute inflammatory mediators, e. $\mathrm{g}$. histamine, GMP-140 is translocated to the cell surface [34] allowing neutrophils to bind. Within $1 \mathrm{~h}$ expression is down-regulated. In contrast ELAM-1 requires de novo gene transcription and protein synthesis. After stimulation of HUVECs by so-called "primary cytokines" IL-1 and tumour necrosis factor(TNF)- $\alpha$, ELAM-1 mRNA is detectable by $1 \mathrm{~h}$, and surface expression maximal at 4 to $6 \mathrm{~h}$; neutrophil binding parallels ELAM-1 expression [9]. Like ELAM-1, VCAM-1 [57] and ICAM-1 [65] induction requires de novo protein synthesis, although ICAM-1 is basally expressed on unstimulated HUVECs. Activation by IL- 1 or TNF- $\alpha$, and in the case of ICAM- 1 also interferon(IFN)- $\gamma$, of HUVECs results in mRNA detection by $2 \mathrm{~h}$ and persistence until at least $72 \mathrm{~h}$. ICAM-1 acts as a ligand for all leukocytes, whereas VCAM-1 binds lymphocytes and eosinophils only [17]. ICAM-2 differs from ICAM-1 in that constitutive expression by HUVECs is stronger but does not appear to be regulated by cytokines [74]. The dynamics of induction of these adhesion molecules may explain why neutrophils accumulate before lymphocytes at sites of inflammation. The significance of these cytokines to inflamed skin and other pro-inflammatory molecules responsible for endothelial activation and adhesion molecule expression will be discussed later. 
The studies outlined above provide much information on the molecular basis for interactions between leukocytes and activated endothelial cells and also demonstrate that selectin- and integrin-mediated pathways are distinct, as indicated by the fact that monoclonal antibodies to each are additive in their inhibition of neutrophil-HUVEC adhesion [11]. Furthermore, when shear forces to simulate blood flow are applied to HUVEC monolayers, selectin-mediated adhesion increases while integrin-mediated adhesion decreases [70]. To assess the dynamics and relative contribution of each pathway in the accumulation of leukocytes at sites of inflammation in vivo, recent experiments in vitro using artificial lipid bilayers containing adhesion molecules [44] and in vivo experiments with blocking antibodies and intravital microscopy [80] have been employed. These demonstrate that under flow conditions similar to those found in post-capillary venules two critical and obligatory interactive phases between neutrophils and endothelial cells operate. Step one involves neutrophils rolling along the luminal surface of activated endothelium, a process which is reversible and selectin (GMP-140, ELAM-1) dependent. Step two, involving irreversible binding and arrest of neutrophils on endothelium followed by diapedesis through the vessel wall is mediated by ICAM-1/LFA-1 interactions and requires prior selectin-mediated adhesion events and neutrophil activation, e.g. by exposure to various neutrophil chemotactic substances including IL-8 (see below).

The relevance of such processes to accumulation of neutrophils at sites of infection is highlighted by the inherited disease "leukocyte adhesion deficiency", (LAD), where affected individuals genetically lack CD18 antigen and consequently develop recurrent life-threatening soft-tissue infections [72]. The sequence of events responsible for lymphocyte/endothelial cell interactions in vivo at sites of inflammation are not yet fully elucidated, although as shown above it is likely that similar molecules are involved in the process.

\section{Molecular basis of cutaneous inflammation}

Accumulation of leukocytes into skin involves three distinct phases, namely (a) recruitment, (b) retention and (c) return to circulation [51]. The initial step in their recruitment into inflamed skin is their interaction with post-capillary venular endothelium in the dermis. These endothelial cells differ from large vessel HUVECs in that they represent microvascular endothelium (human dermal microvascular endothelial cells, HDMEC). Although more difficult to isolate and culture, HDMEC responses to cytokine stimulation are similar to those observed for HUVEC, with up-regulation of ICAM-1, VCAM-1 and ELAM-1 in response to IL-1 and TNF- $\alpha[45,76]$. Certain differences, however, exist: in particular there is stronger constitutive expression of ICAM-1 on HDMECs [76], which is paralleled in vivo by expression of ICAM-1 on dermal vascular cells in normal skin [28] (see below).

Cytokines, including IL-1, TNF- $\alpha$ and IFN- $\gamma$, which play an important role in endothelial activation in vitro, are produced by many cells types within human skin (see below) and are thought to be critical to the pathogenetic mechanisms of many cutaneous inflammatory diseases $[5,52]$. An important experimental 
approach has been to determine the local effects of these cytokines administered intradermally on human skin in vivo. Direct intradermal injection of recombinant human IFN- $\gamma$ produces a significant perivascular infiltrate consisting of lymphocytes and monocytes with few neutrophils. Concomitantly ICAM-1 [2], but not ELAM-1 [31], is up-regulated on endothelium as would be predicted from in vitro studies. Short-term organ culture experiments in which 2-mm punch biopsies of normal skin are immersed for $48 \mathrm{~h}$ in RPMI medium containing IFN- $\gamma$ also lead to enhanced ICAM-1 expression and increased lymphocyte adhesion as assessed by frozen-section adherence assay [53]. Recombinant human TNF- $\alpha$ intradermally leads to a biphasic response. At early time points $(6 \mathrm{~h})$, the infiltrate is predominantly neutrophilic, whereas later (6 days), lymphocytes predominate. ELAM-1, ICAM-1 and VCAM-1 are up-regulated in both groups, indicating that in vivo dynamics may differ from those observed in vitro [32]. In similar experiments performed in baboons, comparable results were achieved when IFN- $\gamma$ or TNF- $\alpha$ were administered separately. When administered together, the cytokines acted synergistically [50], as has also been reported for ICAM-1 and leukocyte chemotactic factor mRNA production in cultured human keratinocytes [3]. Since recombinant IL-1 is not available for administration to humans, autologous stratum corneum-derived IL-1a has been extracted biochemically and re-injected into volunteers [30]. In parallel with in vitro studies, ELAM-1, VCAM-1 and ICAM-1 were up-regulated, and a neutrophilic infiltrate was observed at $6 \mathrm{~h}$. Later time points were not examined.

Cytokine production in skin has been detected in a number of inflammatory conditions, including allergic contact dermatitis (ACD) and psoriasis [1, 52]. To determine whether endothelial adhesion molecule expression is altered in inflamed skin, biopsies of ACD, inflammation following UVB radiation and Mantoux reaction have been examined immunohistochemically. These experimentally induced conditions allow the dynamics of adhesion molecule expression to be assessed in vivo. Elicitation of poison ivy/oak (rhus, urushiol) ACD leads to rapid up-regulation of ELAM-1, VCAM-1 and ICAM-1 by $8 \mathrm{~h}$ and more intense expression at 24-48 h, paralleling the inflammatory infiltrate [29]. Following two minimal erythema doses (m.e.d.) of UVB radiation, ELAM-1 is up-regulated by $6 \mathrm{~h}$, maximal at $24 \mathrm{~h}$ and has returned almost to basal levels by $72 \mathrm{~h} \mathrm{[56].} \mathrm{VCAM-1}$ was not induced and little change was observed in ICAM-1 expression, although this may reflect the strong constitutive expression observed on dermal vascular endothelium in normal skin, and the relative insensitivity of the experimental system to discern changes in intensity of expression. In contrast, Mantoux reactions produced up-regulation of both ELAM-1 and VCAM- 1 by $6 \mathrm{~h}$, with maximal expression persisting to $72 \mathrm{~h}$ [56], probably reflecting stimulus (i.e. antigen) persistence. These studies highlight two important points: firstly, adhesion molecule expression parallels the inflammatory infiltrate, and, secondly, distribution and dynamics of expression vary between inflammatory stimuli. Alterations in endothelial cell adhesion molecules are also observed in chronic inflammatory conditions including psoriasis, lichen planus and atopic dermatitis where ICAM-1 is up-regulated [28] and ELAM-1 chronically expressed [31, 60].

The studies detailed above provide evidence at the phenotypic level for the involvement of endothelial cell adhesion molecules in a range of acute and chronic 
inflammatory skin conditions. Further evidence for their importance is provided by functional studies on murine and human tissue. Using an in vitro lymphocyte/ frozen-skin-section adherence assay it has been shown that lymphocytes specifically adhere to psoriatic endothelium, particularly within the papillary dermis, compared to normal skin [67]. Memory helper T lymphocytes $\left(\mathrm{CD}^{+}{ }^{+}\right.$, CDw $29^{+}$) adhered most prominently [13], a point of considerable interest since this $\mathrm{T}$ cell subset preferentially accumulates in psoriasis and other inflammatory skin diseases as determined by immunohistochemical analysis [58]. Using blocking antibodies to LFA-1 (ICAM-1 receptor on lymphocytes), $40 \%$ of binding activity can be inhibited [13], indicating an important role for this molecule. Furthermore, high endothelial venules which are adapted to support lymphocyte migration into lymphoid tissue, are observed in psoriatic dermis, and may specifically represent the sites of leukocyte recruitment in lesional skin [36]. Frozen-section adherence studies performed on sensitised human skin $18-24 \mathrm{~h}$ following topical urushiol (rhus dermatitis) application demonstrate that lymphocyte adhesion to endothelium can be blocked by monoclonal antibodies to VLA-4 and LFA-1, but is not influenced by antibodies to ELAM-1 [55]. An important role for integrins in mediating recruitment of lymphocytes in skin is suggested by studies in mouse ACD [21]. Lymphocytes extracted from sensitised mice can transfer immunity to syngeneic animals, which upon ear challenge develop swelling. If, however, lymphocytes are incubated with specific integrin receptor peptide sequences, then transfer of immunity is abrogated.

\section{Initiators of dermal endothelium activation (Fig. 1)}

Adhesion of circulating leukocytes to blood vessels requires activation of endothelial cells and concomitant adhesion molecule expression. In vitro and in vivo studies outlined above indicate that this results from the action of soluble inflammatory mediators including peptides (e. g. cytokines), lipid mediators (e. g. PAF) and complement factors (e. g. C5a). Virtually all resident cell types including bone marrow-derived cells, fibroblasts and nerve fibres in the dermis, and keratinocytes in the epidermis, synthesise and release mediators capable of activating endothelium. The relative role of each cell type and mediator is likely to depend upon the underlying pathophysiology of the disease or, in the case of injury or infection, the source and type of initiating agent. Production of factors that inhibit adhesion molecule expression including IL-1 receptor antagonist (IL-1 RA) [33] and transforming growth factor-beta (TGF- $\beta$ ) [24] by resident cells may also be pivotal in delineating the inflammatory responses to various stimuli.

In normal human dermis, blood vessels are surrounded by a cuff of perivascular bone marrow-derived cells such as connective tissue mast cells and helper $\mathrm{T}$ lymphocytes. However, most abundant are dendritic cells of macrophage/monocyte lineage. The immunological importance of these cells is indicated by surface expression of LFA-1, ICAM-1 [12] and VCAM-1(R. W. Groves, unpublished observation) while characterisation is made possible by their cytoplasmic staining for factor XIIIa antigen [35]. By immunohistochemistry, dermal dendrocytes have 


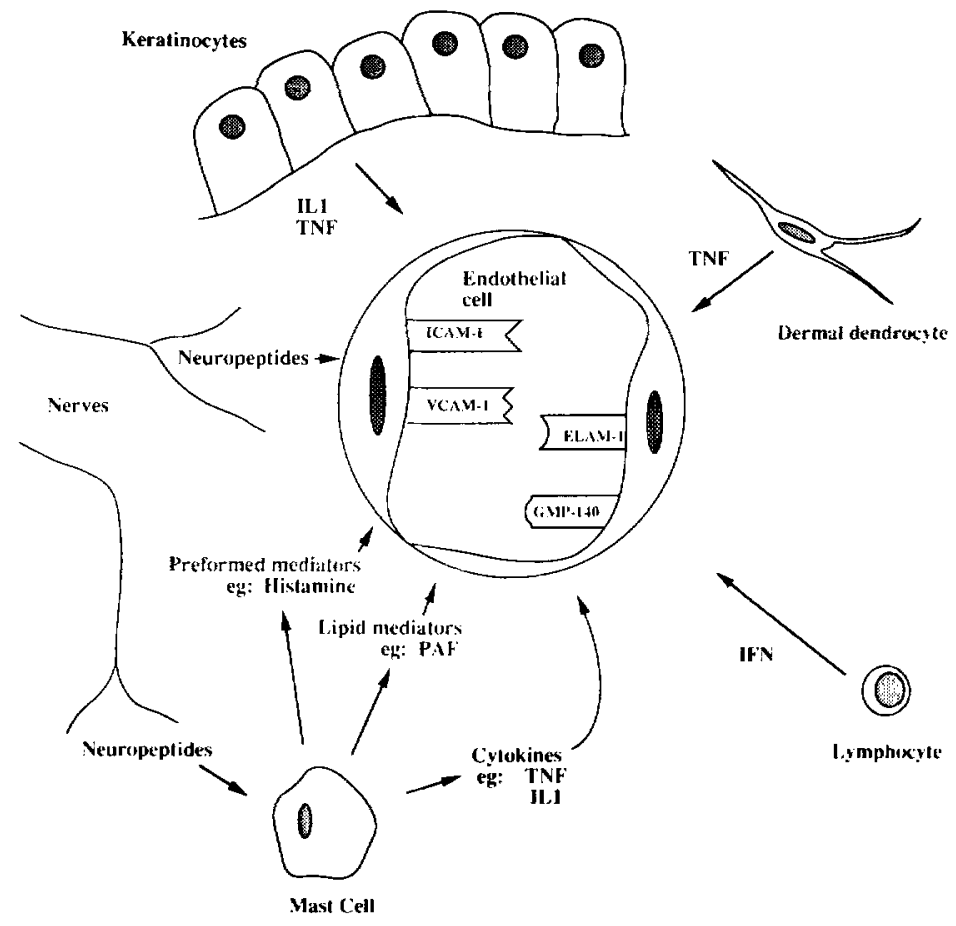

Fig. 1. Schematic representation of potential pathways of vascular endothelium activation in skin. Activated endothelium is indicated by adhesion molecule expression: on left of vessel lumen, immunoglobulin (ICAM-1, VCAM-1), on right, selectins (ELAM-1, GMP-140). Resident cells potentially responsible for providing activation signals are depicted together with examples of mediators. (Figure courtesy of Dr. C. H. Smith)

been show to express TNF- $\alpha$, a potent activator of endothelium, in psoriasis [54]. Characterisation of the complete cytokine profile of these cells will only be possible once isolation and culture can be performed.

Dermal mast cells in normal skin have also been demonstrated by in situ hybridisation to contain TNF- $\alpha$ mRNA and by immunohistochemistry to contain TNF- $\alpha$ protein in cytoplasmic granules [81]. Furthermore, degranulation by various secretagogues leads directly to TNF- $\alpha$ release and ELAM-1 production by endothelial cells [81]. Other important mediators produced by mast cells include PAF, histamine and LTB4. In vitro studies demonstrate that murine mast cells produce a range of pro-inflammatory cytokines including TNF- $\alpha$, IL-1, IL-4 and GM-CSF that may effect endothelial adhesion [64]. That these are of relevance in vivo is suggested by the marked dermal inflammatory infiltrate that results from intradermal injection of mast cell degranulators [38].

Whilst mast cell degranulation may occur in response to specific cross-linkage of the $\mathrm{Fc}$ receptor for IgE, an increasing number of non-IgE-specific stimuli are now recognised including neuropeptides $[23,47]$. Morphological and functional evidence [22] suggest that cutaneous sensory afferent peptidergic nerves form neuroeffector junctions with mast cells. Neuropeptides, such as substance P, 
released in response to various noxious stimuli thus up-regulate ELAM-1 expression, and possibly other adhesion molecules, as a consequence of mast cell degranulation [49]. Some also appear to exert direct effects on endothelium: neuropeptide $Y$, a peptide co-localised with noradrenaline in sympathetic nerves mediates enhanced neutrophil adhesion to isolated endothelial cells by a mechanism independent of protein synthesis or ICAM-1 expression [75]. These findings represent a potentially important link between neurogenic stimuli and inflammation particularly since the number of neuropeptides isolated from human skin continues to increase. Many have already been implicated in human cutaneous disease: increased levels of vasoactive intestinal polypeptide have been demonstrated in both atopic dermatitis and psoriasis [19], whilst pretreatment of skin with capsaicin, which depletes cutaneous nerves of neuropeptides, completely abrogates the physical urticarias [79].

Helper $\mathrm{T}$ lymphocytes upon activation may also produce a range of cytokines including IFN- $\alpha$, TNF- $\alpha$ and IL-4 that affect endothelial activation. The roles of IL-1, TNF- $\alpha$ and INF- $\gamma$ have already been discussed but there is now increasing evidence for an important modulatory role for IL-4 (also produced by mast cells). In vitro, IL-4 increases binding of T cells to HUVECs but inhibits binding of neutrophils [77]. This event is enhanced by the addition of TNF- $\alpha$ and is mediated via induction of VCAM-1 [78]. The possibility exists, therefore, that diseases in which $\mathrm{T}$ cells are prominent but neutrophils sparse may be characterised by IL-4 as an important mediator.

In inflammatory dermatoses involving the epidermis, such as psoriasis, atopic dermatitis, ACD and lichen planus, most dermal inflammatory events occur with dermal papillae. Phenotypic changes of adhesion molecule expression occur on papillary endothelium [1] and functional frozen-section adhesion studies demonstrate that this is the maximal site of lymphocyte adhesion [67]. Under such conditions, epidermal keratinocytes are uniquely situated to provide stimuli required for endothelial cell activation. In a spatial alignment analogous to Bowman's capsule of renal glomeruli, interactions between keratinocytes and endothelial cells, mediated by cytokines [5], are likely to provide the molecular basis for the morphological description of the squirting papilla of Pinckus and Mehregan observed in psoriasis and seborrhoeic dermatitis [61].

Although the primary function of keratinocytes is to provide the stuctural integrity and barrier function of the epidermis, it is increasingly apparent that they play a major role in cutaneous immune responses. Studies have shown that after appropriate stimulation in vitro, multipassaged normal human keratinocytes produce a range of cytokines, including IL-1 [48], IL-6 [39], IL-8 [4], TNF- $\alpha$ [40], GM-CSF [41], MCAF [6] and TGF- $\alpha$ [63], of which IL-1 and TNF- $\alpha$ are particularly potent inducers of endothelial cell adhesion molecule expression. Recent studies in mice demonstrate that administration of anti-TNF- $\alpha$ antibodies prior to elicitation of contact dermatitis abrogates the inflammatory response [62]. Furthermore, by Northern blot analysis, TNF- $\alpha$ mRNA increases in ear skin following application and by in-situ hybridisation TNF- $\alpha$ mRNA is detectable in basal keratinocytes as well as some dermal cells [62]. In humans, TNF- $\alpha$ has been detected in keratinocytes by immunochemistry in experimental patch test reactions (rhus/urushiol dermatitis) [29]. In vitro, potent stimulators for keratinocyte TNF- $\alpha$ 
production include UVB [40] and urushiol [5], both of which provoke cutaneous inflammation in vivo.

IL-8 is a further cytokine produced by keratinocytes [4] in response to a variety of stimuli, including urushiol and UVB, which can be detected in psoriasis [26, $54,68]$ and contact dermatitis [29] in vivo. As well as being chemotactic for neutrophils and $\mathrm{T}$ cells [42], a critical role for this cytokine in modulating neutrophil-endothelium interactions has recently been established (effect on $\mathrm{T}$ cell adhesion has not been reported). IL-8 induces rapid shedding of neutrophil LECAM-1 (GMP-140/ELAM-1 ligand) and up-regulation of $\beta 2$-integrins, thus permitting arrest and diapedesis through the vessel wall [37]. Evidence exists that IL-8 may also be involved in the subsequent loss of adhesion to endothelium [27], allowing neutrophils to then migrate through tissue. Although studies have implicated IL-8 derived from endothelium in these processes, the spatial relationship between keratinocytes and vascular endothelium in dermal papilla suggests a crucial role for keratinocyte-derived IL-8 in these processes.

\section{Conclusions}

It is over 100 years since an active role for vascular endothelium was first established in leukocyte localisation to sites of inflammation. A critical part of this process is now known to be mediated via adhesion interactions between receptors on circulating leukocytes and their ligands, particularly ELAM-1, VCAM-1 and ICAM-1 induced on activated endothelium, allowing leukocytes to "roll", "arrest" and subsequently undergo "diapedesis" through the vessel wall towards the inflammatory focus.

There is increasing evidence linking such mechanisms to leukocyte recruitment into inflamed skin. Intradermal injections of pro-inflammatory cytokines (IL-1, TNF- $\alpha$, IFN- $\gamma$ ) directly induce dermal vascular endothelium adhesion molecule expression which is parallelled by accumulation of a dermal inflammatory cell infiltrate. In experimentally induced cutaneous inflammation, e. g. ACD and UVB radiation exposure, up-regulation of vascular endothlial ICAM-1, VCAM-1 and ELAM-1 expression is observed. Alterations in adhesion both at the phenotypic and functional level are also observed in many other disorders including the inflammatory dermatoses for example psoriasis, lichen planus and atopic dermatitis.

Adhesion molecule expression by endothelium requires activation of these cells by soluble inflammatory mediators including peptides (cytokines), lipid mediators and complement factors. Important constituents of normal human skin that may contribute to this process include fibroblasts, mast cells, dermal dendrocytes and epidermal keratinocytes. The relative role fo each cell type and mediator is likely to depend upon the underlying pathophysiology of the disease or the source and type of the initiating agent.

\section{References}

1. Barker JNWN (1991) Pathophysiology of psoriasis. Lancet 338: 227

2. Barker JNWN, Allen MH, MacDonald DM (1989) The effect of in vivo interferon-gamma on the distribution of LFA-1 and ICAM-1 in normal human skin. J Invest Dermatol 93: 439 
3. Barker JNWN, Sarma V, Mitra RS, Dixit VM, Nickoloff BJ (1990) Marked synergism between tumour necrosis factor-alpha and interferon-gamma in regulation of keratinocyte-derived chemotactic and adhesion molecules. J Clin Invest 85: 605

4. Barker JNWN, Jones ML, Crockett-Torabe E, Mitra RS, Fantone JC, Kunkel SL, Dixit VM, Nickoloff BJ (1991) Modulation of keratinocyte-derived interleukin-8 which is chemotactic for neutrophils and T lymphocytes. Am J Pathol 139: 869

5. Barker JNWN, Mitra RS, Griffiths CEM, Dixit VM, Nickoloff BJ (1991) Keratinocytes as initiators of inflammation. Lancet 337: 211

6. Barker JNWN, Jones ML, Swenson CL, Sarma V, Mitra RS, Ward PA, Johnson KJ, Fantone JC, Dixit VM, Nickoloff BJ (1991) Monocyte chemotaxis and activating factor (MCAF) production by keratinocytes in response to interferon-gamma. J Immunol 146: 1192

7. Beg EL, Yoshino T, Rott LS, Robinson MK, Warnock A, Kishimoto TK, Picker LJ, Butcher EC (1991) The cutaneous lymphocyte antigen is a skin lymphocyte homing receptor for the vascular lectin endothelial cell-leukocyte adhesion molecule 1. J Exp Med 174: 1461

8. Bevilacqua MP, Pober JS, Mendrick DL (1987) Identification of an inducible endothelial leukocyte adhesion molecule. Proc Natl Acad Sci USA 84: 9238

9. Bevilacqua MP, Stengelin S, Gimbrone MA, Seed B (1989) Endothelial leukocyte adhesion molecule-1: an inducible receptor for neutrophils related to complement regulatory proteins and lectins. Science 243: 1160

10. Butcher EC (1990) Cellular and molecular mechanisms that direct leukocyte traffic. Am J Pathol 136: 3

11. Carlos TM, Harlan JM (1990) Membrane proteins involved in phagocyte adherence to endothelium. Immunol Rev 114: 5

12. Cerio, R, Griffiths CEM, Cooper KD, Nickoloff BJ, Headington JT (1989) Characterization of factor XIIIa-positive dermal dendricite cells in normal and inflamed skin. Br J Dermatol 121: 421

13. Chin YH, Falanga V, Taylor JR, Cai JP, Bax J (1990) Adhesion of human helper/memory T cell subsets to psoriatic dermal endothelium. J Invest Dermatol 94: 413

14. Clark ER, Clark EL (1935) Observations on changes in blood vascular endothelium in the living animal. Am J Anat 57: 385

15. Cohnheim $\mathbf{J}(1889)$ Lectures on general pathology, Section 1 - The pathology of the circulation. The New Sydenham Society, London, p 242

16. Diamond MS, Staunton DE, Marlin SD, Springer TA (1991) Binding of the integrin Mac-1 (CD11b/CD18) to the third immunoglobulin-like domain of ICAM-1 (CD54) and its regulation by glycosylation. Cell $65: 961$

17. Dobrina A, Menegazzi R, Carlos TM, Nardon E, Cramer R, Zacchi T, Harlan JM, Patriarca P (1991) Mechanisms of eosinophil adhesion to cultured vascular endothelial cells: eosinophils bind to the cytokine-induced endothelial ligand vascular cell adhesion molecule-1 via the very late activation antigen-4 integrin receptor. J Clin Invest 88: 20

18. Dustin ML, Springer TA (1989) T-cell receptor cross-linking transiently stimulates adhesiveness through LFA-1. Nature 341: 619

19. Eedy DJ, Johnston CF, Shaw C, Buchanan KD (1991) Neuropeptides in psoriasis: an immunocytochemical and radioimmunoassay study. J Invest Dermatol 96: 434

20. Elices MJ, Osborn L, Takada Y, Crouse C, Luhowsky S, Hemler M, Lobb RR (1990) VCAM-1 on activated endothelium interacts with the leukocyte integrin VLA-4 at a site distant from the VLA-4/fibronectin binding site. Cell 60: 577

21. Ferguson TA, Mizutani H, Kupper TS (1991) Two integrin-binding peptides abrogate T cellmediated immune responses in vivo. Proc Natl Acad Sci USA 88: 8072

22. Foreman JC (1992) Substance $P$ and calcitoningene-related peptide: effects on mast cells and in human skin. Int Arch Allergy Appl, Immunol (in press)

23. Fuller RW, Conradson TB, Dixon CMS, Crossman DC, Barmes PJ (1987) Sensory neuropeptide effects in human skin. Br J Pharmacol 92: 781

24. Gamble JR, Vadas MA (1988) Endothelial adhesiveness for blood neutrophils in inhibited by transforming growth factor-beta. Science 242: 97

25. Geng JG, Bevilacqua MP, Moore KL, McIntyre TM, Prescott SM, Kim JM, Bliss GA, Zimmerman GA, McEver RP (1990) Rapid neutrophil adhesion to activated endothelium mediated by GMP-140. Nature 343: 757 
26. Gillitzer R, Berger R, Mielke V, Muller C, Wolff, K, Stingl G (1991) Upper keratinocytes in psoriatic skin lesions express high levels of NAP-1/IL8 mRNA in situ. J Invest Dermatol 97: 73

27. Gimbrone MA Jr, Obin MS, Brock AF, Luis EA, Hass PE, Herbert CA, Yip YK, Leung DW, Lowe DG, Kohr WJ, Darbonne WC, Bechtol KB, Baker JB (1989) Endothelial interleukin-8: a novel inhibitor of leukocyte-endothelial interactions. Science 246: 1601

28. Griffiths CEM, Voorhees JJ, Nickoloff BJ (1989) Characterization of intercellular adhesion molecule-1 and HLA-DR in normal and inflamed skin: modulation by interferon-gamma and tumor necrosis factor. J Am Acad Dermatol 20: 617

29. Griffiths CEM, Barker JNWN, Kunkel S, Nickoloff BJ (1991) Modulation of leucocyte adhesion molecules, a T-cell chemotaxin (IL-8) and a regulatory cytokine (TNF-alpha) in allergic contact dermatitis (rhus dermatitis). Br J Dermatol 124: 519

30. Groves RW, Ross E, Ross J, Camp RDR, Barker JNWN, MacDonald DM (1992) Stratum corneum derived IL-1 alpha modulates adhesion molecule expression in vivo. J Invest Dermatol 98: 384

31. Groves RW, Allen MH, Barker JNWN, Haskard DO, MacDonald DM (1991) Endothelial leucocyte adhesion molecule-1 (ELAM-1) expression in cutaneous inflammation. Br J Dermatol 124: 117

32. Groves RW, Ross E, Barker JNWN, MacDonald DM (1992) Effect of acute and chronic administration of tumour necrosis factor-alpha in normal human skin (abstract). J Invest Dermatol 98: 510

33. Hannum CH, Wilcox C J, Arend WP, Joslin FG, Dripps DJ, Heimdal PL, Armes LG, Sommer A, Eisenberg SP, Thompson RC (1990) Interleukin-1 receptor antagonist activity of a human interleukin-1 inhibitor. Nature 343: 336

34. Hattori R, Hamilton KK, Fugate RD, McEver RD, Sims PJ (1989) Stimulated secretion of endothelial von Willebrand factor is accompanied by rapid redistribution to the cell surface of the intracellular granule membrane protein GMP-140. J Biol Chem 264: 7768

35. Headington JT (1986) The dermal dendrocyte. In: Callen JP, Dahl MV, Golitz LE (eds.): Advances in Dermatology, vol 1. Yearbook Medical Publishers, Chicago, p 159

36. Heng MCY, Allen SG, Chase DG (1988) High endothelial venules in involved and uninvolved psoriatic skin: recognition by homing receptors on cytotoxic $\mathrm{T}$ lymphocytes. $\mathrm{Br} \mathrm{J}$ Dermatol 118 : 315

37. Huber AR, Kunkel SL, Todd RF III, Weiss SJ (1991) Regulation of transendothelial neutrophil migration by endogenous interleukin- 8 . Science 254: 99

38. James MP, Kennedy AR, Eady RA (1981) A microscopic study of inflammatory reactions in human skin induced by histamine and compound 48/80. J Invest Dermatol 78: 406

39. Kirnbauer, R, Kock A, Schwarz T, Urbanski A, Krutmann J, Borth W, Damm D, Shipley G., Ansel JC, Luger TA (1989) IFN-beta-2, B cell differentiation factor 2, or bybridoma growth factor (IL-6) is expressed and released by human epidermal cells and epidermoid carcinoma cell lines. J Immunol 142: 1922

40. Kock A, Schwarz T, Kirnbauer R, Urbanski A, Perry P, Ansel JC, Luger TA (1990) Human keratinocytes are a source for tumor necrosis factor alpha: evidence of synthesis and release upon stimulation with endotoxin or ultraviolet light. J Exp Med 172: 1609

41. Kupper TS, Lee F, Birchall N, Clark S, Dower S (1988). Interleukin 1 binds to specific receptors on human keratinocytes and induces granulocyte macrophage colony-stimulating factor mRNA and protein. $\mathrm{J}$ Clin Invest 82: 1787

42. Larsen CG, Anderson AO, Apella E, Oppenheim JJ, Oppenheim, Matsushima K (1989) The neutrophil-activating protein (NAP-1) is also chemotactic for T lymphocytes. Science 243: 1464

43. Larsen E, Palabrica T, Sajer S, Gilbert GE, Wagner DD, Furie BC, Furie B (1990) PADGEMdependent adhesion of platelets to monocytes and neutrophils is mediated by a lineage-specific carbohydrate LNF III (CD15). Cell 63: 467

44. Lawrence MB, Springer TA (1991) Leukocytes roll on a selectin at physiologic flow rates: distinct from and prerequisite for adhesion through integrins. Cell 65: 859

45. Lee KH, Lawley TJ, Xu Y, Swerlick RA (1992) VCAM-1, ELAM-1 and ICAM-1 independent adhesion of melanoma cells to cultured human dermal microvascular endothelial cells. J Invest Dermatol 98: 79

46. Lowe JB, Stoolman LM, Nair RP, Larsen RD, Berhend TL, Marks RM (1990) ELAM-1 depen- 
dent cell adhesion to vascular endothelium determined by a transfected human fucosyl transferase cDNA. Cell 63: 475

47. Lowman, MA, Benyon RC, Church MK (1988) Characterisation of neuropeptide-induced histamine release from human dispersed skin mast cells. Br J Pharmacol 95: 121

48. Luger TA, Stadler BM, Katz SI (1981) Epidermal cell-derived (keratinocyte) thymocyte activating factor (ETAF). J Immunol 127: 1493

49. Matsuda H, Kavalita K, Kiso Y, Nakano T, Kitamura $Y$ (1989) Substance $P$ induces granulocyte infiltration through degranulating mast cells. J immunol 142: 927

50. Munro JM, Pober JS, Cotran RS (1989) Tumor necrosis factor and interferon-gamma induce distinct patterns of endothelial activation and associated leukocyte accumulation of skin of Papio Anubis. Am J Pathol 135: 121

51. Nickoloff BJ (1988) Role of gamma-interferon in cutaneous trafficking of lymphocytes with emphasis on molecular and cellular adhesion events. Arch Dermatol 124: 1835

52. Nickoloff BJ (1991) The cytokine network in psoriasis. Arch Dermatol 127: 871

53. Nickoloff BJ, Griffiths CEM (1989) T lymphocytes and monocytes bind to keratinocytes in frozen sections of biopsy specimens of normal skin treated with gamma interferon. J Am Acad Dermatol 20: 736

54. Nickoloff BJ, Karabin GD, Barker JNWN, Griffiths CEM, Sarma V, Mitra RS, Elder JT, Kunkel SL, Dixit V (1991) Cellular localization of interleukin-8 and its inducer-tumor necrosis factoralpha in psoriasis. Am J Pathol 138: 129

55. Nickoloff BJ, Stoof TJ, Mitra RS, Griffiths CEM, Aulicino M, Stoolman LM (1991) CD-18 (LFA-1) and CD49d (VLA-4) mediate lymphocyte adherence to endothelial cells in rhus dermatitis (abstract). J Invest Dermatol 96: 538

56. Norris P, Poston RN, Thomas DS, Thornhill M, Hawk J, Haskard DO (1991) Expression of ELAM-1, ICAM-1 and VCAM-1 and VCAM-1 in experimentally induced cutaneous inflammation: a comparison of ultraviolet B erythema and delayed hypersensitivity. J Invest Dermatol 96: 763

57. Osborn L, Hession C, Tizzard R, Lobb R (1989) Direct expression cloning of vascular cell adhesion molecule-1, a cytokine-induced endothelial protein that binds to lymphocytes. Cell 59: 1203

58. Picker LJ, Michie SA, Rott LS, Butcher EC (1990) A unique phenotype of skin-associated lymphocytes in man: preferential expression of the HECA-452 epitope by benign and malignant T-cells at cutaneous sites. Am J Pathol 136: 1053

59. Picker LJ, Warnock RA, Burns AR, Doerschuk CM, Berg EL, Butcher EC (1991) The neutrophil selectin LECAM-1 presents carbohydrate ligands to the vascular selectins ELAM-1 and GMP-140. Cell 66: 921

60. Picker LJ, Kishimoto TK, Smith CW, Warnock RA, Butcher EC (1991) ELAM-1 is an adhesion molecule for skin-homing T cells. Nature 349: 796

61. Pinkus H, Mehregan AH (1966) The primary histologic lesion of seborrheic dermatitis and psoriasis. J Invest Dermatol 46: 109

62. Piguet PF, Grau GE, Hauser C, Vassalli P (1991) Tumor necrosis factor is a critical mediator in hapten-induced irritants and contact hypersensitivity reactions. J Exp Med 173: 673

63. Pittelkow MR, Lindquist PB, Abraham RT, Graves-Deal R, Derynck R, Coffey RF (1989) Induction of transforming growth factor-alpha expression in human keratinocytes by phorbol esters. J Biol Chem 264: 5164

64. Plaut M, Pierce JH, Watson CJ, Hanley-Hyde J, Nordans RP, Paul WE (1989) Mast cell lines produce lymphokines in response to cross-linkage of FceRI or to calcium ionophores. Nature 339: 64

65. Pober JS, Gimbrone MA, Lapierre LA (1986) Overlapping patterns of activation of human endothelial cells by interleukin-1, tumour necrosis factor and immune interferon. J Immunol 137: 1893

66. Rothlein R, Dustin ML, Marlin SD, Springer TA (1986) A human intercellular adhesion molecule (ICAM-1) distinct from LFA-1. J Immunol 137: 1270

67. Sackstein R, Falanga V, Streilein JW, Chin Y-H (1988) Lymphocyte adhesion to psoriatic dermal endothelium is mediated by a tissue-specific receptor/ligand interation. J Invest Dermatol 91: 423

68. Schroder JM, Christopher E (1986) Identification of C5a des arg and an anionic neutrophilactivating peptide (ANAP) in psoriatic scales. J Invest Dermatol 98: 53 
69. Shimizu Y, Shaw S, Graber N, Vopal TV, Horgan KJ, Van Seventer GA, Newman W (1991) Activation-independent binding of human memory $T$ cells to adhesion molecule ELAM-1. Nature 349: 799

70. Smith CW, Kishimoto TK, Abbass O, Hughes B, Rothlein R, McIntire LV, Butcher E, Anderson DC (1991) Chemotactic factors regulate lectin adhesion molecule 1 (LECAM-1)-dependent neutrophil adhesion to cytokine-stimulated endothelial cells in vitro. J Clin Invest 87: 609

71. Springer TA, Lasky LA (1991) Sticky sugars for selectins. Nature 349: 196

72. Springer TA, Thompson WS, Miller LJ (1984) Inherited deficiency of the Mac-1, LFA-1, p150, 95 glycoprotein family and its molecular basis. J Exp Med 160: 1901

73. Staunton DE, Marlin SD, Stratowa C, Dustin ML, Springer TA (1988) Primary structure of ICAM-1 demonstrates interaction between members of the immunoglobulin and integrin supergene families. Cell 52: 933

74. Staunton DE, Dustin ML, Springer TA (1989) Functional cloning of ICAM-2, a cell adhesion ligand for LFA-1 homologous to ICAM-1. Nature 339: 61

75. Sung CP, Arleth AJ, Feurerstein GZ (1991) Neuropeptide Y up-regulates the adhesiveness of human endothelial cells for leucocytes. Circ Res 68: 314

76. Swerlick RA, Garcia-Gonzales E, Kubota Y, Xu Y, Lawley TJ (1991) Studies of the modulation of MHC antigen and cell adhesion molecule expression on dermal microvascular endothelial cells. J Invest Dermatol 97: 190

77. Thornhill MH, Kyan-Aung U, Haskard DO (1990) IL-4 increases human endothelial cell adhesiveness for $T$ cells but not for neutrophils. J Immunol 144: 3080

78. Thornhill MH, Wellicome SM, Mahiouz DL, Lanchbury JSS, Kyan-Aung U, Haskard DO (1991) Tumor necrosis factor combines with IL- 4 or IFN- $\gamma$ to selectively enhance endothelial cell adhesiveness for T cells. J Immunol 146: 592

79. Toth-Kasa I, Jansco G, Obal F, Husz S, Simon N (1982) Involvement of sensory nerve endings in cold and heat urticaria. J Invest Dermatol 80: 34

80. von Andrian UH, Chambers JD, McEvoy LM, Bargatze RF, Arfos KE, Butcher EC (1991) Twostep model of leukocyte-endothelial cell interaction in inflammation: distinct roles for LECAM-1 and the B2 integrins in vivo. Proc Natl Acad Sci USA 88: 7538

81. Walsh LJ, Trinchieri G, Waldorf HA, Whitaker D, Murphy GF (1991) Human dermal mast cells contain and release tumor necrosis factor alpha, which induces endothelial leukocyte adhesion molecule 1. Proc Natl Acad Sci USA 88: 4220 